\title{
Multiple, connective intellection: the condition for invention
}

\author{
$C S D E B E E R^{1}$ \\ I prefer invention accompanied by the danger \\ of error to rigorous verification, which is \\ paralleled by the risk of immobility - in \\ philosophy as in life, in life as in the sciences.
}

Michel Serres

\begin{abstract}
Since this article involves invention, the conditions for inventiveness become the issue: assuming multiple reality; thinking in a special way; transgressing boundaries; acknowledging networks (in the terms of Michel Serres: communication, transduction, interference, distribution, passages between the sciences. There are, however, misplaced expectations: technology should work wonders in this regard while forgetting that humans, redefined though, remain the key to establish connections and networks between people, paradigms, disciplines, sciences and technologies.

Against this background, Michel Serres's emphasis on invention and "thinking as invention" and his a-critical anti-method - 'connective, multiple intellection' which is a special kind of thought - are desperately needed.

Guattari's articulation of the three ecologies and the ecosophic views he developed in this regard provides a significant amplification of the approach of 'multiple connective intellection'. These insights can be enlightened and strongly driven home through the views of Latour with an anthropological and socio-dynamic perspective on the scientific endeavour with the articulation of the actor-network theory inherited from Serres. The thoughtful beyond-methodology of Edgar Morin with his strong noological position as the ultimate condition for inventiveness, and Gregory Ulmer with his special emphasis on invention and inventiveness, especially with the help and assistance of electronic means (video and internet), and with his work with the architect Bernard Tschumi on invention and inventiveness, are of special significance in the sphere of inventiveness, the real and final guarantee for a spirited re-enchantment of the world as well as the final demonstration that the battle for intelligence as opposed to ignorance, stupidity and barbarism can be fought with great hope to succeed.
\end{abstract}

Keywords: A-critical approach, actor-network theory, beyond-metod, complexity, ecosophy, euretic conditions, invention, inventiveness, multiple connective intellection, routes to invention, sets of conditions for invention,

\section{Introduction}

Invention is what is at issue here. We encounter very complex situations, problematic and challenging to the extreme: the political, the social, the natural, the moral, the individual and their intimate interconnectedness. We do not have models or examples of situations like this

1. Prof. C S (Fanie) de Beer, Department of Information Science, University of Pretoria. E-mail: fanie.debeer@up.ac.za 
to follow. We have to find something new; we have to think new, fresh, differently, which means ... we have to invent.

\subsection{The problem is vast}

With our focus on the re-enchantment of the world we need to realise that re-enchantment presupposes disenchantment. This is a problem, a serious problem that implies crises and catastrophes. Briefly, our time is characterised by disenchanting situations ... the scope is comprehensive, deep-seated and vast. The disenchantment affects almost all facets of our lives in one way or another.

Valéry $(1978,2009)$ described the situation caused by the two world wars as diabolic and as symptomatic of the debasement, or the devaluation of spirit and spirituality with the ultimate consequence of disenchantment of the world - as a matter of fact as an insult to what it means to be human. This diabolic situation of spiritual debasement is still with us and manifests itself around us in many human facial expressions and in a diversity of situations.

Stiegler uses Valéry's diagnosis but takes it much further, right to the heart of individual and social situations of the contemporary Zeitgeist. According to him and the group of researchers associated with him, the implications (perhaps also the symptoms) of disenchantment is symbolic misery, ontological misery, individual misery, intellectual misery (stupidity, ignorance), societal misery, economic misery, environmental misery and institutional misery. This is a grim picture - too pessimistic, we may feel, until we attend to the news (local and international) week after week only to realise that matters may still be euphemistically articulated.

Felix Guattari (2012:19) is very explicit about this, but in a different way. He describes the situation as follows: "The Earth is undergoing a period of intense techno-scientific transformations. If no remedy is found [in other words, the implications and impact of the transformations are by no means innocent - they require remedy], the ecological equilibrium this has generated will ultimately threaten the continuation of life on the planet's surface. Alongside these upheavals, human modes of life, both individual and collective [kinship networks, domestic life, family and married life, neighbourhood relations], are progressively deteriorating ... It is the relationship between subjectivity and its exteriority ... that is compromised in this way, in a sort of general movement of implosion and regressive infantalization".

To this Guattari adds: "The increasing deterioration of human relations with the socius, the psyche and the 'nature' is due not only to environmental and objective pollution but is also a result of a certain incomprehension and fatalistic passivity towards these issues as a whole, among both individuals and governments. Catastrophic or negative developments are simply accepted without question. We are accustomed to a vision of the world drained of the significance of human interventions. ... This decline appears to be the result of the failure of social and psychological praxes to adapt, as well as a certain blindness to the erroneousness of dividing the Real into a number of discrete domains [digital, virtual, alternate, cyber, etc]". (Op.cit.: 28). And then he continues: "Chernobyl and Aids [And we may add Fukushima and the much earlier atomic bomb], have dramatically revealed to us the limits of humanity's techno-scientific power and the 'backlash' that 'nature' has in store for us (Ibid.). (Cf Laszlo 1989 on 'the inner limits of mankind').

In order to emphasise the fatal importance of these events one may add the comments of Michel Serres (1984) in an interview on the atomic bomb and its decisive impact on the 
relationship between science and society, and on the explosion of the spaceship Challenger with its serious implications for our scientific endeavours and its societal consequences. His answer to the question, "Why are you a philosopher?" was unambiguously explicit: "Because of Hiroshima." (Serres 1984:186). And then he continues: "Knowlegde was in such a way glued to power and violence that the end of this history was Hiroshima. ... This decisive event of Hiroshima that is our history. ... Hiroshima is behind us and in front of us. ... My call for the obligation to retreat aims at rethinking the conditions of knowledge, of power, and of science in order to go beyond this stupid history. All philosophical undertakings of other times come up against this point. Why am I a philosopher? Because of Hiroshima, there is no doubt. Hiroshima is the first act which has organised my life [When he was 15] and have made me say: I always withdraw myself in front of violence in order to try to know [understand] and to act differently/otherwise" (1984:202-3).

Nancy's discussion of Fukushima in terms of 'the equality of catastrophes' (2012) and Dupuy's studies on both Chernobyl and Fukushima and the nuclear menace (2005, 2006, 2013) should be a timely warning to all those so eagerly and uncritically willing to embrace nuclear power developments as the only solution to energy problems. Too many people prefer to remain ignorant and turn a blind eye to the consequences spelled out in these studies - a deliberate strategy of disenchantment and a demonstration of the reign of stupidity and a complete lack of responsible intelligence. Many others join them, for example Stengers (Catastrophe and the barbarism to come), Steiner (On the barbarism of ignorance) and Michel Henry (Barbarism).

Guattari (2012:45) sees these problems, seated in an extremely complicated reality, as "the major crises of our era", especially with a view to its implications for the articulation between the three ecological registers (the environment, social relations and human subjectivity). They call for a clear understanding of the complex nature of the real.

\subsection{Reality in its full complexity}

Given our current general scientific and disciplinary situation we have to consider the following emphases on science by some formidable thinkers and scientists on the rich domain of scientific work as the most general condition for invention. Michel Serres emphasises the following distinction: "One can say that knowledge has two modes: The concern with verification and the burdens it requires, but also risk taking, the production of newness, the multiplicity of found objects - in short, inventiveness." (Serres/Latour, 1995:126). Deleuze and Guattari distinguish between arboreal and rhizomic cultural forms with drastic implications for methodological approaches. "The former is stable, centered, hierarchical; the latter is nomadic, multiple, decentered." (Poster 2001:27). Henri Atlan (1986), in his 'essay on the organisation of the living' distinguishes two dimensions of the real on both of which science should constantly focus: "the rigidity of minerals (crystal) and the decomposition of smoke" and then he continues: "What do the attributes 'organise' and 'complex' mean when one applies them to natural systems [to the real], not totally mastered by humans because not constructed by them? It is here that the two opposed notions of repetition, regularity and redundance on the one side, and variety, improbability and complexity on the other side, have been able to be disengaged and recognised as co-existing ingredients in dynamic organisations. These organisations appeared to compromisebetween two extremes: a perfectly repetitive symmetric order of which crystals are the most classical physical models, and an infinitely complex variety, unforseeable in its details, as the order of evanescent forms of smoke." (Atlan 1986:3) (My translation). Emphasis on only the first item in these two 
distinctions is an immense impoverishment of the scientific endeavour and closes the road to invention, while emphasis on both, and especially on the second aspect or mode, opens up wide possibilities for inventions. If we get stuck on the first, as generally happens in our research endeavours, we close ourselves off from inventive initiatives and possibilities with severe limitations on possibilities of the solution to problems that harass humankind and its future to catastrophic dimensions. The scope of what is threatening is vast! Dealing with it poses a severe challenge!

Given this complexity of the real it should be realised that no superficial solutions should even be contemplated. As a matter of fact, an alternative to the current foci of scientific or research approaches generally pursued ought to be intelligently explored. And when we read Stengers (2013) such an endeavour should not be impossible.

\subsection{Existing responses do not satisfy}

Therefore, considering the scope and depth of the crises and the vast scope of the real something special, something out of the ordinary, is required. It is, however, fully uncertain whether we are geared for it, whether the capacity exists to confront the challenge of the crises. What is 'of the ordinary' in terms of our dealings with problems, deepens the problems rather than solving them. It is of the utmost importance to get clarity about the situation discussed here and to be willing to face it with honesty and sincerity. There are examples of individuals who are taking these steps in a confident way: The views of Ivan Illich (1973:8-9) in his Tools for conviviality are not only clear, but also very disturbing. He writes "While evidence shows that more of the same leads to utter defeat, nothing less than more and more seems worthwhile in a society infected by the growth mania. ... It has become fashionable to say that where science and technology have created problems, it is only more scientific understanding and better technology that can carry us past them. The cure for bad management is more management. The cure for specialized research is more costly interdisciplinary research, just as the cure for polluted rivers is more costly non-polluting detergents. The pooling of stores of information, the building up of a knowledge stock, the attempt to overwhelm present problems by the production of more science is the ultimate attempt to solve a crisis by escalation".

Felix Guattari is explicit about the close link between the lack of success in solving problems and mere symptomatic treatment thereof. He writes: "Political groupings and executive authorities appear to be totally incapable of understanding the full implications of these [critical] issues. Despite having recently initiated a partial realization of the most obvious dangers that threaten the natural environment of our societies, they are generally content to simply tackle industrial pollution and then from a purely technocratic perspective, whereas only an ethico-political articulation - which I call ecosophy - between the three ecological registers (the environment, social relation and human subjectivity) would be likely to clarify these questions." (Guattari 2012:19-20).

Gregory Ulmer is equally explicit in his acceptance of the presupposition regarding the almost guaranteed lack of success with problem solving when he states "that every manner of problem-solving now at work - every mode of application of knowledge to living - is inadequate, insufficient, requiring supplementation ..." (Ulmer 1990:160). The date of some of these sources does not nullify their pertinent significance and importance. On the contrary, in many respects their crises have been aggravated on a global and even lethal scale. 
In order to achieve the "supplementation" Ulmer writes about, the ecosophic pole of Guattari and the tools for conviviality of Illich, we have to look for something new and unique - some call it innovation and some invention. It is important to distinguish between innovate and invent. Etymologically speaking they are totally different; they are not interchangeable despite the fact that this occurs quite regularly.

Innovate means to renew, refresh, rethink and re-do; improve the existing and build on it; it remains a linear approach in the extension of the techno-scientific approach. The assumption on which it is based is a fixed and objectifiable reality. The problem posed is the continuation of the existing that may lead to impressive changes but without any significant solutions.

Invent (heuresis) on the other hand refers to something drastically and radically new, different - beyond the ordinary. The assumption here is that it is based on the wealth, inexhaustibility of complex and dynamic reality. Something totally new is in principle always possible. Invention makes real and significant transformations of the world and life conditions possible.

The critical circumstances and conditions we face are of such a nature that they require more than mere innovation. An inventive spirit is required. Central to solutions are inventions. There are no standard and ready-made answers available. What we have available are our own abilities, which are enormous and underestimated, and which must be identified, cultivated and utilised at all cost.

When invention is central to solutions the very first step required is the reinvention of spirit and spirituality, and intelligence, of course. (Both terms are translations of the Greek term nous! ([Stiegler (2015:196vn50; 266] \& Gadamer [1994]; Cf also Stiegler and Ars Industrialis, 2014). The spiritual as characterised by Valéry and Stiegler is, however, of vital and decisive importance in all of these to inspire and invigorate all of them.

\section{Routes to and conditions for invention}

As focus of this article I have decided to briefly discuss five routes that will take us beyond, to the other side of, the known, the existing, the settled, the accepted, the stereotyped, the fixed and the linear and towards the inventive, or into the domain of invention. We can also, alternatively, consider articulating this inventive initiative as the creation of different sets of conditions appropriate for facilitating acts of invention. These routes or sets are not only complementary but refer to each other (interreferential), have an impact on each other and reinforce each other. They offer excellent illustrations of scientists who take the full scope of science and reality as suggested earlier in the introduction seriously.

These five sets of conditions or routes are:

1. Multiple, connective intellection, or, a set of intellectual conditions (Serres)

2. Three ecologies, or, a set of ecosophic conditions (Guattari)

3. Actor-network theory, or, a set of socio-dynamic conditions (Latour)

4. A position beyond-method, or, a set of paradigmatic conditions (Morin)

5. Heuretics, or, a set of euretic conditions (Ulmer/Tschumi) 
2.1 The route of multiple connective intellection, or, a set of multiple intellectual conditions (Serres)

An exploration of "intellection" is of the utmost importance here as the key term for Serres. Intellection as used by Serres can be interpreted as an excellent translation of the Greek nous which can be translated as spirit and/or intelligence. The understanding of spirit in the sense made explicit above brings us in direct contact with the adjectives Serres uses to qualify intellection, namely multiple and connective. Reality as multiple and as an interconnected manifestation of all its facets and aspects calls for a singularly unique human capacity that can be called intellection, or spirit, a capacity enabling humans to fathom the depths and wealth of the real, of that which is. It is the intellection that has an awareness and sensitivity for the multiple and the capacity to establish connections and that enables humans to act compositionally, in other words to compose a world where humans are at home. It is not and has never been the case that humans had to wait for technology in order to connect. Since human intellection is central as the connecting principle of the multiple real, and merely developing and using technical aids to amplify and strengthen this intellectual capacity, the phrase of Serres 'multiple connective intellection' has been chosen as the theme of the article. 'This phrase says it all, all about the real and all about thought, and is the only human intellectual capacity that enables humans to re-enchant the world intelligently, and as a necessary consequence also meaningfully.

Given our traditional and generally accepted scientific and disciplinary situation we have to consider the following: "One can say that knowledge has two modes: The concern with verification and the burdens it requires, but also risk taking, the production of newness, the multiplicity of found objects - in short, inventiveness.” (Serres/Latour, 1995:126). Michel Serres is adamant about the shortcomings of the traditional methodological approaches. He writes: "We have at our disposal tools, notions, and efficacy, in great number; we lack on the other hand, an intellectual sphere free of all relations of dominance. Many truths, very little goodness. A thousand certainties, rare moments of invention". (Serres/Latour 1995:136). Also compare his remarks on method when he states that repeating a method is profoundly boring and nothing but a kind of laziness (Op. cit.:100). His views on method are summarised aptly by Harari and Bell (1983: xxxvi): "The term method itself is problematic because it suggests the notion of repetition and predictability - a method that anyone can apply. Method implies also mastery and closure both of which are detrimental to invention. On the contrary Serres's method invents: it is thus an anti-method." Method means literally to be on the road, a made road, with the implication that we can see only what is visible from the road and nothing else. In order to see more we have to leave the road and move away, "off the beaten track". The real exciting places are often to be found there.

Serres's a-critical approach of "multiple connective intellection" is developed in a rich oeuvre of more than 40 books dealing with themes such as science, knowledge, humans, information, ecology and foundations. My focus here is briefly on his five books on the philosophy of information organised around the theme of the wing-footed messenger-god of the Greeks, Hermes. This should be more than adequate for our purposes. These publications have specific relevance for information and our thinking about information and knowledge, information messages and communication and information work with strong suggestions about the research endeavours related to these themes and sub-themes. Let us never forget that methodology, despite the fact that it relates to the work of research, is always, without any exception, a work of thought in a special sense, that is in the sense of intellection as qualified here. That is why "intellection" is such a central theme. It helps us to 
move beyond and away from the exclusivity and rigidities of method and the blind spots created by it. A new space of understanding opens up here. This means the end of a philosophy of interpretation and the beginning of 'a pluralist logic'. We are forced to rethink the human cogito, the thinking capacity of humans, as a mutation of the cogito, in other words (Cf Crahay 1988). The thinking capacity of humans, understood in this 'mutated' way, enables us to apply compositional thinking as suggested already. Serres teaches us a thought of multiple entries so that we can explore other roads, other spaces. It is a thought of forms that exchanges representation for interference (a title of one of his five books), or of interreference as he suggested in this book, and that brings us back to "connective intelligence". With this kind of thought the possibility of the re-enchantment of the world opens up widely. This thinking is a model for inventiveness that Serres regards predominantly important. He writes: "Invention is the only true intellectual act, the only act of intelligence. The rest? Copying, cheating, reproduction, laziness, convention, battle, sleep. Only discovery awakens. Only invention proves that one truly thinks, whatever that may be. I think therefore I invent, I invent therefore I think .... The inventive breath alone gives life, because life invents" (Serres 1997:92-93). With a view to re-enchantment our desperate need is a need for invention. Why? Serres's reply: "I prefer invention accompanied by the danger of error to rigorous verification [innovation], which is paralleled by the risk of immobility - in philosophy as in life, in life as in the sciences." (Serres/Latour 1995:131). The views of Serres's immensely interesting philosophy of information and knowledge have been made explicit in a much more extensive way in another article (See De Beer 2014b).

2.2 The route of the three ecologies in terms of an ecosophy, or, a set of ecosophic conditions (Felix Guattari)

Guattari is explicit: the three ecologies (the environment, social relations and subjectivity in its singularity) must be articulated properly for crises and catastrophes to be avoided. We are accustomed to a vision of the world drained of the significance of human interventions of care and wisdom - the vision of a disenchanted world. The problem is: "The increasing deterioration of humanity's relations with the socius, the mental, and 'nature' is due not only to environmental and objective pollution but is also the result of a certain incomprehension and fatalistic passivity towards these issues as a whole, among both individuals and governments. Catastrophic or not, negative developments are simply accepted without question" (Guattari 2012:28).

It will be necessary to deal with these problems in order to rescue the relations.

How to rectify? The emphasis will be on the three ecologies and their interconnectedness. Alternatives along these lines should be invented (Cf Guattari 2012:36-38). They are, although complex and difficult, non-negotiable prerequisites. This dealing implies a recomposition of the objectives and the methods of the totality of the social movement under the conditions of today. This calls for a different way of thinking (thinking transversally) and a different kind of logic, a logic of intensities or eco-logic. (See Guattari 2012:29-30).

What Guattari is called for is an ethico-aesthetic articulation of the three ecologies which he calls an 'ecosophy'. Etymologically ecosophy means the wisdom of the household. The most central principle of this wisdom is care, to take care and to give care. It is the ways of living on this planet that are at issue here and to what extent these ways of living are threatened from various angles and perspectives. The ecosophic focus is that of "the production of human existence itself in new historical contexts". (Op. cit.:24). This mental ecosophy, that can be translated as an ecosophic intellection (cf. previous section on Serres), an intellection 
in charge of the wisdom of the household, "will lead us to reinvent the relation of the subject to the body, to phantasm, to the passage of time, to the mysteries of life and death." It operates more like an artist than in terms of "an outmoded model of scientificity" (Ibid). And then he continues: "I have stressed these aesthetic paradigms because I want to emphasise that everything, ...has to be continually reinvented, started again from scratch, otherwise the processes become trapped in a cycle of deathly repetition. The precondition [for any reinvention] .... consists in accepting that as a general rule, ...individual and collective subjective assemblages are capable, potentially, of developing and proliferating well beyond their ordinary equilibrium." (Op. cit.:27). "Every care organization or aid agency, every educational institution, and any individual course of treatment ought to have as its primary concern the continuous development of its practices as much as its theoretical scaffolding" (Ibid.). Complementary to this he emphasises then the importance of 'a narrative element' which is indispensable for inventive theorization. "All theoretical bodies of the type [that are deployed on a truly industrial scale, particularly by the media and public institutions] share the shortcoming of being closed to the possibility of creative proliferation." (Guattari 2012:36-37). (Cf Stengers \& Schlanger 1991).

This ethico-political articulation, called ecosophy (the wisdom of the household), between the three ecological registers, the one of the environment, nature, world, the one of the socius, social relations, the us, human togetherness, and the one of the mental, the subjectivity, the psychic, the noological should be inclined to clarify all questions related to these emerging issues. (See Guattari 2012:19-20). His tri-ecological vision is articulated by Guattari as follows: "To bring into being other worlds beyond those of purely abstract information, to engender universes of reference and existential territories where singularity and finitude are taken into consideration by the multivalent logic of mental ecologies and by the group eros of social ecology; to dare to confront the vertiginous Cosmos so as to make it inhabitable." (Guattari 2012:44). This seems to be a superb articulation of the reenchantment of the world and according to him "the only escape from the major crises of our era”.

Highly significant to constantly keep in mind: No problem is ever a problem in isolation but always in context (and here I am not thinking of the material, physical context which of course exists!)- all three of the ecological domains are at issue here. If we encounter a problem or cluster of problems regarding water (as one example of many other critical issues) and all possible dimensions thereof, it is never only a problem of nature, the environment or the worldly. The problem also relates very intensely and strongly to the mental (how people think about water, what they know about water, how they relate to water - ethics) and also to the social (my family, my friends are affected by polluted water; political leaders are involved or perhaps not involved with the problem - ethics as well). In his reflections on the nature of problems Deleuze (1994:57-64) is of specific importance here with a clear confirmation of the previous remarks. He writes: "We are led to believe that problems are ready-made, and that they disappear in the response or the solution.... We are led to believe that the activity of thinking ... begins only with the search for solutions... This belief has its origin in the dogmatic [image of thought]: puerile examples taken out of context and arbitrarily erected into models. According to this infantile prejudice, the master sets a problem, our task is to solve it, and the result is accredited true or false by a powerful authority." (Deleuze 1994:158). The dogmatic image of thought supports "the postulate of responses and solutions according to which truth and falsehood only begin with solutions or only qualify responses. When, however, a false problem is 'set' ... this propitious scandal serves only to remind us 
that problems are not ready-made but must be constituted and invested in their proper symbolic fields. ...[P]roblems must be considered not as 'givens' (data) but as ideal 'objecticities' possessing their own sufficiency and implying acts of constitution and investment in their respective symbolic fields" (Deleuze 1994:158-159). Such an understanding of problems opens up a door for inventions, not necessarily of solutions, but of truth and falsehood about situations in the symbolic fields.

2.3 The route of the actor-network theory, or a set of socio-dynamic conditions (Bruno Latour)

The core meaning of the actor-network theory entails the following: "An actor-network is what is made to act by a large star-shaped web of mediators flowing in and out of it. It is made to exist by its many ties: attachments are first, actors are second." (Latour 2005:217). It is clear that the issue of connectivity in the widest possible sense is emphasised here and will be well illustrated in the discussion that follows.

These seem to be very obvious conditions for invention.

Michel Serres should be credited with the honour of initiating this theoretical approach. For invention to happen, new and multiple connections are imperative, implied by the notion of network. But invention is an act, of course, and more specifically an intellectual activity, and self-evidently the kind of activity assumed in this theory. The five horizons of Latour (1995) is an effort to do exactly that.

Scientific thought and work are embedded in networks of societal institutions and discourses in its widest sense which unavoidably determines to a great extent the direction scientific work will take. It is important to acknowledge these 'forces' and influences in order for inventive possibilities to take shape. Latour (1995:27) excellently sketches the tension between scientist and science administrator, "It is impossible to give account of scientific ideas in a correct way if one separates it from the network of relations within which it gains significance" (Latour 1995:27).

Latour emphasises the networks within which science development occurs which is common knowledge but the way in which he tries to articulate their interconnectedness and its implications for invention are quite impressive. "The solidity of a discipline does not depend on its isolation but on its relationships and its implications." (Latour 1995:28). This means that the impact of a discipline on its environment and the changes in life situations it manages to bring about is decisive for its acknowledgement, its power and its status. This holds true for philosophy and for information science. All disciplines should attend to the influence and significance of the implications of what they articulate in order to secure their future but also to serve science in general.

The following five horizons of researchers sketched by Latour must be related to the social intelligence of all disciplines and researchers in such a way that the solidity of scientific truth is not going to get lost but rather confirmed and expanded in the direction of invention: i) mobilisation of the world; ii) autonomisation of researchers; iii) alliances; iv) public relations; v) famous concepts, ideas, theories (Latour 1995:22 - 28) - vocabulary building - or the 'theoretical scaffolding' of Guattari.

The first category of tasks scientists must set to work should aim to obtain a "mobilisation of the world" that traverses all the disciplines. Each discipline should mobilise the world in a certain way through the instruments used: laboratory equipment, instruments of observation, opinion surveys, questionnaires, diagrams, texts, interpretative strategies, an so forth. This 
enterprise of mobilising the world constitutes a solid part of scientific activity and firmly situates scientists regarding their function and role in society.

The second horizon or part of activities is totally different and is about the "creation of colleagues" or the "autonomisation of research", which means the mobilisation of people who are capable of understanding what one is doing and saying. Those who are able to understand are also those who are able to attack, to criticise and to engage in sensible debate. These colleagues are those who are able to detest but also able to read and to evaluate. This kind of community is indispensable for the best possible science. Creating an autonomous world of science and research demands much work such as identifying suitable and interested colleagues and organising them in new professions, establishing institutions, and creating journals. Different capacities are required than are required for the first horizon. One is not born a scientist but one becomes one.

The third horizon requires a third type of capacity: "strategic [inventive] intelligence". It concerns the alliances with people that one can use to realise the preceding operations, namely the mobilisation of the world and autonomisation of colleagues and institutional activities. This is a category of activities clearly distinct from the previous two, and includes the justification of autonomous institutions and professions, promising and motivating the significance and the usefulness of one's endeavours in order to obtain the necessary means and mobilising important resources and gathering financial support for the scientific enterprise among those who may not be easily persuaded like government officials, military figures, medical representatives, educational leaders, environmental activists, and business and other interest groups.

The fourth horizon is about the activities that are applicable to public relations in general, of the product of scientific activity in general and the solution to problems that can sometimes be extremely delicate and which are born from the contradictions between the other three horizons and this one. It relates to public relations, ideological convictions, personal convictions, and matters of impact. Confidence in scientific work must be constructed. All great disciplines are familiar with these problems: evolutionism, pasteurisation, genetics are examples of enormous but also highly problematic and even questionable impact.

These four horizons are mostly studied separately which does not facilitate the development of a global understanding of problems and even less to the invention of solutions to these problems. For this reason a fifth horizon is required that can establish links and connections.

Latour is explicit: Are ideas towards changing and inventing of a scientific, administrative, technological or industrial nature? Not any one of them but all of them at the same time. "It is impossible to give correct account of scientific ideas if one detaches them from the network of relations in which they take up meaning in order to give account of themselves. Therefore the importance of giving full credit (light) to concepts. Far from developing a disinterest in concept let us learn to consider the concept for what it is: a strategic [inventive] entity. This is what allows to remain interested in and keep a hold on one's world" (Latour 1995:27-28). This absolutely crucial matter is often forgotten: it is about the contents of scientific activity, these famous contexts and these famous ideas ... These contents play an essential role of linking and connecting the previous four horizons. These ideas and these concepts are strong enough to link even more horizons and as such are opening the way to inventions. They are not isolated in their knot but remain linked to what they connect. These ideas and concepts enable all mobilised actors to be held together and to act together. This emphasises the importance of vocabulary building but also the idea of Guattari of 'theoretical scaffolding'. Do

TD, 11(2), November 2015, Special edition, pp. 122-140. 
not forget the deeply significant insights of Stengers and Schlanger (1991) and Schlanger (1983) into concepts and invention. Language is of fundamental importance to excel in scientific work and inventive activities. Poverty of language guarantees scientific impoverishment.

\subsection{The route of a position beyond-method, or, a set of paradigmatic conditions (Edgar} Morin)

It is of vital importance to keep Morin in mind when invention is at stake. His six major books on The Method deal with the following themes: the nature of nature, the life of life, the knowledge of knowledge, the ideas: their habitat, life, morals and organisation (noology and noosphere), humans (the humanity of humanity), and ethics are integrated and not separated and isolated items - they are interweaved! That links up with his pertinent views on paradigm from which authentic knowledge can emerge. What is this view?

It remains important to realise that the inclination to ignore or to deny complexity of the real will cut us off from any real possibility of invention. Simplified reality offers extremely limited scope for invention, for the new ... anything new. Re-enchantment is for all practical purposes ruled out of the equation.

Edgar Morin's guidance in this respect of a beyond-method, as worked out in the six volumes, is crucial. All these exciting themes mentioned above are interconnected in various ways and are organised around the central notion of method and that makes them even more exciting and inspiring. He stated firmly: "We are in need of a method of knowledge that translates the complexity of the real, recognises the existence of beings, and approaches the mystery of things. ... The method of complexity demands the conceptualisation of the relationship between order/disorder/organisation; the refusal to reduce phenomena to their constitutive elements, nor to isolate them from their environments; the rejection of the dissociation of the problem of the knowledge of nature from the nature of knowledge." (Morin 1977: 3-4, own translation). This, he says, is "the voyage to the search for a mode of thought that would respect the multi-dimensionality, the richness, the mystery of the real and that would know that the cerebral, cultural, social and historical determinations that subject all thought co-determine the objects of knowledge. This is what I call complex thinking." (Morin 1980:10, own translation). According to him it is self-evident that a rejection of these "a-methodical" or "beyond-methodical" approaches would lead to "a pathology of knowledge" that materialises in the increase of ignorance and in the mutilation of knowledge." (Morin 1986:13-14, own translation). Equally crucial is his work on paradigm (already explicitly emphasised in the previous chapter), especially his focus on "the science of the knowing mind, or noology" that is capable of dealing with what he calls the "paradigmatic knot" as the space or place where "the multi-determined character of knowledge finds expression which has its determinations in the individual, anthropological, noological, socio-cultural and psychoanalytical structures of the knowing mind" (Morin 1983:11-12: see also Morin 2008:236).

Morin's views on paradigm should be kept in mind. It is not in line with the generally accepted superficial understanding of paradigm as merely referring to the different approaches of method such as empiricism and constructivism. His idea of paradigm is the following: "All knowledge operates through the selection of meaningful data and the rejection of data that are not meaningful. ... These operations, which use logic, are in reality driven by "supralogical" principles of organization of thought, or paradigms: the hidden 
principles that govern our perception of things and of the world, without our being conscious of them." (Morin 2008:2)

What exactly is this noology to which paradigm is linked? It is a play with ideas, a play of ideas; it is a matter of linking and connecting ideas and of allowing ideas to emerge, to appear, to become active. According to Morin, it is a move into the sphere of ideas - the noosphere (Cf Morin 1991). What needs to be mentioned is that this noosphere is not an abstract, totally inaccessible domain. No, it is close by; it is here, precisely here where we, all of us - in our sciences and in our practices - are working and thinking. It links and connects science and services in order to become a forceful energy in the transformation and informatisation of society! Without this strong connection both science and service come to nothing. We cannot avoid it; we cannot escape from it. It is explored by Morin (1990) under 'the methodology of complexity' where he describes a noological situation beyond-method. Noology is the human thought capacity to come to terms with the two essential and very complex dimensions of the knowable, namely the measurable and the immeasurable (or even the measureless) (Bernardis \& Hagene 1995). These two dimensions (or two worlds), and the necessity to keep them linked in an intricate way, are well articulated by a number of scientists from a diversity of so-called scientific disciplines: Monod (1979) (biologist), Weizenbaum (1984) (computer scientist), Atlan (1986) (biologist), Ekeland (1988) (mathematician), Wersig (1990) (information scientist) and Serres (1995) (philosopher). Many more can be added to this list.

This new reform also represents a new vision. It opens up new epistemological perspectives. Two worlds, or rather, two visions of the world, confront each other: The one inherited from Modernity and of a classical vision of science; the other, a rupture from Modernity and inseparable from new developments in science (thermodynamics, microphysics, astrophysics) (Morin 1977:95). Here follows a brief summary of Fortin's fine overview of Morin's work (2008:54) in terms of these two visions of the world. The first is founded on the ideas of order, determinism, necessity, clarity, certainty and measurement; the second is founded on the unity of order and disorder, on the impossibility of eliminating uncertainty, ambiguity, chance and risk. Two related and interdependent visions of the world, united by a common trunk (the progress of science and the progress of thought), but incapable of letting dialogue and communication emerge between them. The six volumes of "The Method" is not an indictment against science, but is an effort on behalf of science, as an open, non-reductive, reflexive and self-critical, and even a-critical science. It is a road, a voyage which is the search for a way of thinking capable to confront the complexity of the real, able to recognize the wealth and the mystery of the real, and to respect the multidimensionality of physical, biological, social, cultural, cerebral determinations that all knowledge and all thought undergo. Of this we find ample demonstrations in library material and collections.

The Method is a kind of spiral movement which crosses and explores different territories in crossing and exploring different knowledges in order to make communicate which does not communicate, but must communicate: phusis, bios and anthropos. They are, all of them, connected. This calls for a re-organization in the chain of knowledge, which calls for a constant combat and a struggle against all modes of disjunctive, reductive, and simplifying thought. The first enemy of complexity is simplification: reductive, idealist, atomizing, totalizing, systemic and cybernetic. It is this enemy that Morin, through the whole of The Method, tries to track down in assuring the betting for the "transformation of his conviction about complexity into a method of complexity" (Morin 1980:457). And this method, if it can formulate itself, can only formulate itself at the end, because method is road, a road not 
traced in advance, as we do as a matter of habit, but a road which makes itself or is made, in the process of marching or walking (Fortin 2008:88-89).

This approach is Morin's way of avoiding the abstract, one-dimensional view, the principles of disjunction, reduction and abstraction that constitutes the "paradigm of simplification". "This paradigm has dominated the adventure of Western thought since the seventeenth century. It has without doubt made great progress in scientific knowledge and in philosophic reflection possible. Its ultimate noxious consequences did not begin to become clear until the twentieth century."(Morin 2008:3). The problem is that the principle of disjunction isolates the three main branches of scientific knowledge, namely physics, biology and the human sciences in such a radical way in terms of disciplinary arrangements of specialisation that it ultimately deprives science of knowing itself and reflecting on itself. This simplification automatically leads to another simplification, namely simplifying reality by tearing up and fragmenting the complex fabric of reality to such an extent that scientific knowledge necessarily built its rigour on measurement and calculation. The ultimate consequence is the destruction of unities, totalities and complexities, or, what Morin calls "blind intelligence". Blind intelligence misses the necessary connection of objects to their environments, of problems to other problems, of observers to what they observe, of humans to human sciences and of spirit to the sciences of spirit. The consequence for Morin is that "we are approaching an unprecedented mutation of knowledge. Knowledge is less and less made to be reflected upon and discussed by human minds or intelligences, and it is more and more made to be imprinted in memory banks and manipulated by anonymous powers, particularly by nation states, and economists of knowledge. It blocks all possible roads to invention. "This new, massive and prodigious ignorance is itself ignored by scientists." (Op. cit.:4) And the consequence: "Whereas the media produces mass ignorance, the university produces high ignorance."(Ibid.). But moreover: "Unfortunately, this mutilating, one-dimensional vision is taking a cruel toll on human phenomena. The mutilation wounds flesh, spills blood, spreads suffering. ... The inability to conceive of the complexity of anthroposocial reality [that certainly includes noology and the noosphere] ... has led us to infinite tragedies and is leading us to supreme tragedy." (Op. cit.:5). To avoid catastrophes, the final dis-enchantment of the world, and the ultimate fatal consequences of stupidity and ignorance "it is essential to first become aware of the nature and the consequences of paradigms that mutilate knowledge and disfigure reality" (Op.cit:3), and embrace paradigms that honours knowledge, reality, human spirituality and the spirit of invention.

\subsection{Heuretics - the solid focus on invention, or, a set of euretic conditions (Ulmer/Tschumi)}

The core here is that language of reason and language of madness (unreason) when combined in unexpected ways may create something new. This complementary view, that relates unrelated, and according to many unrelatable areas, ideas, and forms, is well-developed by Gregory Ulmer in a number of publications, the latest of which is his Internet invention (2003). Apart from his very illuminating exploration of the value of Beuys and Kandinsky for the learning of inventiveness (See Ulmer 1985 and De Beer 2008 in this regard), he devotes much attention, perhaps not adequately acknowledged, to the role of the electronic media in cultivating inventiveness. As a matter of fact the very idea of a knowledge society is in a direct sense linked to the impact of electronic media developments on the creation, dissemination and utilization of knowledge.

His development of what he calls a 'teletheory' with the emphasis on theoretical developments for the age of the video is extremely relevant here. (Ulmer 1989). In line with 
this he also proposes 'heuretics' as "the use of theory to invent forms and practices, as distinct from 'hermeneutics' which uses theory to interpret existing work" (Ulmer 2003:4-5). Internet invention concerns how the new technologies might affect our working conditions and teaching practices [and certainly also learning experiences], and what we might do to reduce the negative aspects and enhance the positive. According to his understanding "the one negentropic force in the world is human intelligence (creativity): we should consider this moment as a time for invention." (Ibid.)

We encounter problems, crises, catastrophes. How to deal with them in the context of these views is the significant question that must be attended to.

"In conventional consulting, the founding assumption is that problems, or the people who are in a position to do something about problems, are tractable by means of reason, rational argument and authenticated evidence. There is, of course, overwhelming evidence to the contrary ... having to do with the political dimension of social reality [but also with the inexhaustible nature of reality as such] but consulting persists just the same way because there seems to be no other way, no alternative for the delivery of knowledge to problems. Given this presupposition, that every manner of problem-solving at work - every mode of application of knowledge to living - is inadequate, insufficient, requiring supplementation, how should we then work ourselves? It relates to the question: how to deliver disciplinary knowledge to the public at the site of the greatest need, at the site of confrontations, catastrophes, problems in the life world. The task is: to find a means to utter more than we know, to reflect on what emerges out of the accidents and on the margins of our arguments, to see if we can learn how to make sense [ and to do it collectively].(Ulmer 1990:161).

Tschumi shows us the design of a possible alternative, however, and he calls it 'madness' (folie). His madness is an alternative procedure for bringing materials into relation with one another, which is to say it is an alternative logic. We aim, he writes, to consider the architect first as a formulator, an inventor of relations. (See Ulmer 1990: 167).... Tschumi's plans 'to encourage cultural invention' show the structure of relations that produce invention. Invention tends to occur when unrelated areas, ideas, or forms come together in unexpected ways. It implies the dismantling of institutional conventions. The example of psychoanalysis/delirium can certainly be complemented with examples from prophesy and poetry where phantasm, imagination and reverie plays a major role in envisioning and inventing the new, new ways of thinking about the world, the real, socius and society, and about being human and possible human futures.

In view of the problem with problem-solving as sketched above and complementary to Tschumi's way of approaching this dilemma Ulmer (2003) also articulates in a special way an additional approach: "An [inventional consultant] egent treats a public issue not as "problem" but as "aporia". The difference is that conventional consultants look for that aspect of social difficulties that lend itself to pragmatic solutions, while inventional consultants (for the newcoined French word 'egents') might look at the same difficulties but call attention to that in them which is impossible. Most of the theorists in our repertoire, as summed up by Heidegger, consider the human condition itself to be aporetic, irreparable. The "impossible" dimension refers to this limit-condition..." (Ulmer 2003:299). The socio-material reality of the total environment in which we live is so complex and comprehensive that it resists our projects of problem-solving and the limited knowledge and means that these efforts are based on with disastrous consequences. Ulmer (2003:300) makes it explicit: "The collective disaster helps reveal the individual "foolishness" (or vice versa). The theory is that any practical 
solution to the breakdown or disasters in the civic realm is limited finally by two other dimensions of disaster that calculative thinking neglects: the ultimate limitation of human capacity at the macro level of cosmology; and the fundamental incompleteness - the wound of individual identity. The goal of this exercise is to test the affective capacity of the wide image precisely in its nature as "wide" - its ability to mediate your relation to world situations outside your biography." This certainly reminds us of the explicit views expressed by Laszlo (1989) on 'the inner limits of humankind' and the vital importance of coming to terms with this phenomenon as a severely limiting factor in the invention of solutions to human problems.

We have to move beyond calculative thinking and its disastrous limitations and beyond personal biographies and its fatal consequences in order to reach the real core of the issues involved like the full scope of 'the total environment' in which we live, the depth of the reality of 'world situations' that go far beyond our personal and even collective boundaries. The logic of the problem and problem-solving as a possibility should be put in tension with the essential presence of aporia and its impossibilities, 'the impossibilities that refers to the limit-condition which is a condition of 'there is no way out' (Ausweglos of Heidegger). Where we encounter aporia, defined as "the point at which the problematic task becomes impossible and where we are exposed to, absolutely without protection, without problem, and without prosthesis, without possible substitution...in this place of aporia, there is no longer any problem ... only 'barred paths', 'I am stuck', 'I am helpless' (as synonyms for aporia) (Derrida 1993:12, 13). The aporia is a promise for an alternative logic (that reminds of the alternative logic of Guattari with the emphasis on the fact that we cannot afford to stick to one kind of logic given the scope and complexity and disappearance of the real). Derrida (1986:134) writes: "I believe that we would misunderstand [aporia] if we tried to hold it to its most literal meaning: an absence of path, a paralysis before road-blocks, the immobilization of thinking, the impossibility of advancing, a barrier blocking the future. On the contrary it seems to me that the experience of the aporia, ... gives or promises the thinking of the path, provokes the thinking of the very possibility of what still remains unthinkable or unthought, indeed, impossible. The figures of rationality are profiled and outlined in the madness of the aporetic" (Derrida 1986:134). The 'madness of the aporetic' reminds of Tschumi's fascination with the language of the mad in order to create a gap for invention.

In a recent publication Badiou (2015) in a book 'on the search for lost reality' emphasises that the 'impossibility of the real' is not at all hopeless, but it needs a different kind of approach, perhaps an inventive approach in the sense invention is used here: "today we must be convinced that in spite of the disasters and the deaths that thought imposes on us, the search for this that is real in the real can be, and is, a joyful passion" (Badiou 2015:60).

With regard to the inventive or euretic classroom: it does something other than convey and receive precise messages - the 'normal' processes of communication. It is concerned with inference rather than communication. A course is designed to create gaps in texts - in the totality of information - and to provide the means, designs and rhetoric to fill these gaps. That is the function of composition. As Bernard Stiegler (2009:72) emphasises, we are in a natural sense inclined to oppose things instead of composing them. The result of such a decomposition is diabolic and as such a very dangerous strategy of disturbance and disintegration in the context of learning as well as teaching in the knowledge society. Compositional thinking is in line with the new image of thought explored and promoted by Gilles Deleuze and offers as such an absolute condition for inventiveness. 
The inventive or euretic assignment derives a basic principle of composition from Alice in Wonderland: the appropriation of Alice (or some other now mythical figure) as an organisational principle, as though Alice were a kind of index or mnemonic system. These figures are neither symbol nor allegory: they are inventio and memoria. (Cf Deleuze 1990 on sense and non-sense, in a book devoted to or at least inspired by Alice in Wonderland).

With regard to the student of euretics, the student who really wants to invent: How can students use this formula for encounters in wonderland in order to liberate, organise and mobilise any amount of information, any terrain of knowledge? The point at issue is not the specific content of a package; the point is that the holders or possessors of the information are the ones who unpack it. The student as reader is confronted with the totality of information or with a specific amount of it; this happens in the euretic classroom, which provides the area or space for inventive encounters. Students compose a scene out of the items - a mnemonic scene - or they dramatize an event, depict a place, bearing in mind throughout that the procedure is also a method of inventiveness, a manner of writing, a theoretical experiment.

What this article therefore proposes is that the euretic classroom should trade reproduction for inventiveness, strict methodology (dogmatic thinking) for a theoretical indulgence in hobbies (anti-method), sterile memorisation for playful writing, and stark and dull research for the entrance into the gardens of wonderland. (Ulmer 1991, De Beer 2008).

All this calls for intellectual exercise according to the new perception of thinking, also called intellection; in other words, mobility between a thousand plateaus and through multiples of multiplicity. But ... "Learning to think: our schools no longer have any idea what this means" (Nietzsche). This stratum of meaning simply has to be restored to our students (schools). Our competence to do so depends on the extent to which we are still victims of the dogmatic perception of thought or intellect (For a comprehensive exposition of the dogmatic image of thought see Deleuze 1994:129-167). We conclude with Deleuze's sketch of an alternative new image of thought, into which students need to be inducted or introduced: "Empedocles and his volcano - this is an anecdote of a thinker. The height of summits and caves, the labyrinths; mid-day - mid-night; the halcyon aerial element and also the element of the subterranean. It is up to us to go to extreme places, to extreme times, where the highest and the deepest truths live and rise up. The places of thought are the tropical zones frequented by the tropical man, not temperate zones or the moral, methodical or moderate man" (Deleuze, 1983:110). That is the domain or space of the inventive or of the euretic experience, the space in which new knowledge emerge on a regular scale!

\section{Conclusion}

From these five theoretico-practical explorations, with a view to their significance for the invention of solutions to vital life-important solutions to threatening problems we derive the following suggestions:

They are interconnected and complementary and active and relevant far beyond disciplinary boundaries and should be reflected upon as such. Three crucial terms should be embraced wholeheartedly, do we really wish to be inventive in the context of the threats, catastrophes, disenchantment, and stupidity regarding environmental, socio-cultural and spiritually individual settings of a disenchanted world: multiple/multiplicity; connectivity/compositionality; intelligence/spirituality.

They are essential to all five routes towards or sets of conditions necessary for inventive endeavours, each time in a unique and singularly different way. 
And these three terms tie the five routes or sets of conditions (acritical, ecosophic, noological, irreductionistic, euretic) together into a strong unique comprehensive scope that include the multiple richness of the real in all its facets and dimensions and the wealthy capacity of human inventive capabilities. The challenge of complying with these sets of conditions requires a strong focus on and willingness towards wholeheartedly embracing human spirituality and a complementary keenness for the learning to invent.

\section{Bibliography}

Atlan, H. 1986. Entre le cristal et la fumée : essai sur l'organisation du vivant. Paris: Seuil.

Badiou, A. 2015. À la recherche du réel perdu. Paris: Fayard.

Bernardis, M-A. \& Hagene, B. 1995. Mesures et démesure. Paris: Les Éditions de la Cité des Sciences et de l'Industrie.

Crahay, A. 1988. Michel Serres: La mutation du cogito. Brussels: De Broeck-Wesmael.

De Beer, C. S. 2008. Learning to invent: let the new knowledge come, in The Open Knowledge Society: a computer science and information systems manifesto, edited by M.D.Lytras, et al. Berlin: Springer Verlag.

De Beer, C.S. 2014a. Die herbetowering van 'n ont-towerde wêreld. Tydskrif vir geesteswetenskappe, 54(2):205-216.

De Beer, C.S. 2014b. Michel Serres' multidisciplinary philosophy of information and knowledge. The Journal for transdisciplinary research in Southern Africa, 10(1):1936.

Deleuze, G. 1983. Nietzsche and philosophy. London: Athlone.

Deleuze, G. 1990. The logic of sense. New York: Columbia University Press.

Deleuze, G. 1994. Difference and repetition. New York: Columbia University Press.

Derrida, J. 1986. Memoires: For Paul de Man. New York: Columbia University Press.

Derrida, J. 1993. Aporias. Stanford: Stanford University Press.

Dupuy, J-P. 2005. Petite metaphysique des tsunamis. Paris: Seuil.

Dupuy, J-P. 2006. Retour de Tchernobyl: journal d'un homme en colère.Paris: Seuil.

Dupuy, J-P. 2013. The nuclear menace: a new sacrament for humanity, in The mark of the sacred. Stanford: Stanford University Press.

Ekeland, I. 1988. Mathematics and the unexpected. Chicago: Chicago University Press.

Fortin, R. 2008. Penser avec Edgar Morin: lire La méthode. Quebec: Les Presses de L’Université Laval.

Gadamer, H-G. 1994. Being Spirit God, in Heidegger's ways. New York : State University of New York Press.

Guattari, F. 2012. The three ecologies. London: Continuum.

Harrari, J.V. \& Bell, D.F. 1983. Introduction: Journal a plusieurs voies, in Serres, M 1983.

Henry, M. 2012. Barbarism. London: Continuum. 
Illich, I. 1973. Tools for conviviality. London: Calder \& Moyars.

Laszlo,E. 1989. The inner limits of mankind: heretical reflections on today's values, culture and politics. London: Oneworld Publications.

Latour, B. 1995. Le métier de chercheur regard d'un anthropologue. Paris: INRA Éditions.

Latour, B. 2005. Reassembling the social: an introduction to actor-network theory.Oxford: Oxford University Press.

Monod, J. 1979. Chance and necessity. London: Collins Fount Paperbacks.

Morin, E. 1977. La méthode: 1. La nature de la nature. Paris: Seuil.

Morin, E 1980. La méthode: 2. La vie de la vie. Paris: Seuil.

Morin, E. 1983. Social paradigms of scientific knowledge. SubStance, 39:3-20.

Morin, E. 1986. La méthode: 3. La connaissance de la connaissance. Paris: Seuil.

Morin, E. 1990. Introduction à la pensée complexe. Paris: ESF éditeur.

Morin, E. 1991. La méthode: 4. Les Idées: leur habitat, leur vie, leurs moeurs, leur organisation. Paris: Seuil.

Morin, E. 2008. On complexity. Cresskill (NJ): Hampton Press, Inc.

Nancy, J-L. 2012. L'Équivalence des catastrophes (Après Fukushima). Paris: Galilée.

Poster, M. 2001. What's the matter with the internet? Minneapolis: University of Minnesota Press.

Prigogine, I. \& Stengers, I. 1997. Re-enchantment of the world, in Stengers, I. 1997.

Schlanger, J. 1983. L'Invention intellectuelle. Paris: Fayard.

Schlanger, J. 1991. La pensée inventive, in Stengers, I. \& Schlanger, J. 1991.

Serres, M. 1969. Hermès I: La communication. Paris: Minuit

Serres, M. 1972. Hermès II: L’Interfèrence. Paris: Minuit

Serres, M. 1974. Hermès III: La traduction. Paris: Minuit.

Serres, M. 1977. Hermès IV: La distribution. Paris: Minuit.

Serres, H. 1980. Hermès V: Le passage Nord-Ouest. Paris: Minuit.

Serres, M. 1983. Hermes: Literature, science, philosophy, edited by J.V. Harrari \& D.F. Bell. Baltimore: The Johns Hopkins University Press.

Serres, M. 1984. Entretiens avec Le Monde, 1. Philosophies: Michel Serres. Paris: La Découverte.

Serres, M. 1997. The troubadour of knowledge. Ann Arbor: The university of Michigan Press.

Serres, M. 2007. The parasite. Minneapolis: The University of Minnesota Press.

Serres, M. 2008. The five senses: a philosophy of mingled bodies. London: Continuum Books.

Serres M \& Latour, B 1995. Conversations on science, culture and time. Ann Arbor:The University of Michigan Press.

TD, 11(2), November 2015, Special edition, pp. 122-140. 
Steiner, G. \& Spire, A. 1998. Barbarie de l'ignorance: collection conversations. Latresne: Le bord de l'eau.

Stengers, I. 2009. Au temps des catastrophes: résister à la barbarie qui vient. Paris: La Découverte.

Stengers, I. 2013. Une autre science est possible! Manifeste pour un ralentissement de sciences. Paris: La Découverte.

Stengers, I. \& Schlanger, J. 1991. Les concepts scientifiques: Invention et pouvoir. Paris: Gallimard.

Stiegler, B. 2009. Acting out. Stanford: Stanford University Press.

Stiegler, B. 2014. The re-enchantment of the world: the value of spirit against industrial populism. London: Bloomsbury.

Stiegler, B. 2015. States of shock: stupidity and knowledge in the $21^{\text {st }}$ Century. Cambridge: Polity Press.

Ulmer, G. 1985. Applied grammatology. Baltimore: The Johns Hopkins University Press.

Ulmer, G 1989. Teletheory: grammatology in the age of video. New York: Routledge.

Ulmer, G. 1990. Confrontation (For a new consultancy). Oxford Literary Review, 1990: 155 $-169$.

Ulmer, G. 1991. The euretics of Alice's valise. Journal of Architectural education, 45: 3-10. Press.

Ulmer, G. 2003. Internet invention: from literacy to electracy. New York: Longman

Valéry, P. 1978. La crise de l'esprit, in Variété 1 et 2. Paris Gallimard.

Valéry, P. 2009. La liberté de l'Esprit, in Regards sur le monde actuel et autres essais. Paris: Gallimard.

Weizenbaum, J. 1984. Computer power and human reason: from judgment to calculation. Harmondsworth: Pelican Books.

Wersig, G. 1990. The changing role of knowledge in an information society, in The information environment: a world view, edited by D.J. Foskett. New York: Elsevier Science. 